\title{
Budget win for climate probe
}

NASA gets cash to replace a failed carbon-emissions observatory, but concerns remain over future funding.

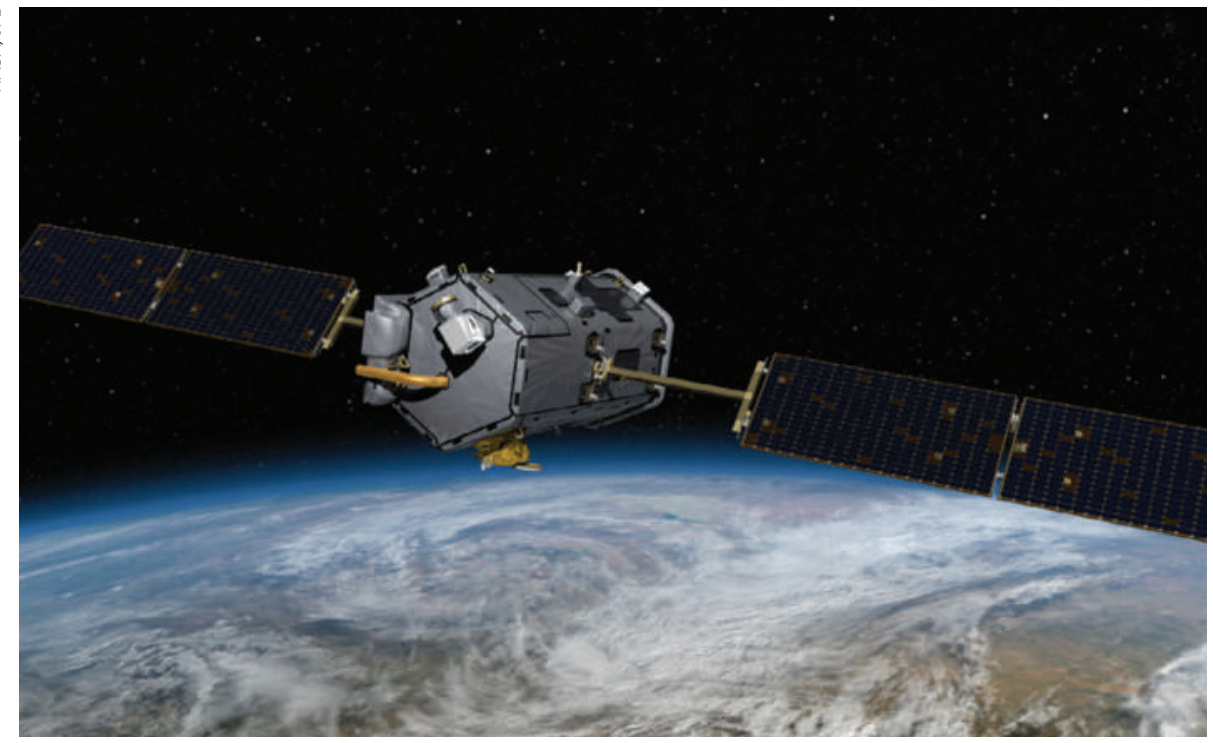

The replacement Orbiting Carbon Observatory will monitor Earth's carbon sinks and sources.

The US Congress is ratcheting up demands for NASA to launch Earth-monitoring satellites that could help to verify the emissions targets currently being debated in Copenhagen.

In a US\$447-billion spending bill approved on 13 December (see table), lawmakers told NASA to spend $\$ 50$ million in fiscal year 2010 on a replacement for the Orbiting Carbon Observatory (OCO), which crashed into the ocean near Antarctica in February after a rocket failure. "It looks like there is a future here," says David Crisp, the mission's principal investigator at the Jet Propulsion Laboratory in Pasadena, California. But by adding the OCO to NASA's already long list of Earth-science missions - and with no promise of future funding - some Earth scientists worry that Congress is asking the agency to do too much. Berrien Moore, director of Climate Central, a think tank in Princeton, New Jersey, says that he was both "pleased and worried" by the OCO funding because of the additional burden on the mission programme.

By measuring levels of atmospheric carbon dioxide, the OCO could provide baseline emissions data and act as a proof-of-concept that carbon sources and sinks can be monitored from space. The observatory would measure $\mathrm{CO}_{2}$ changes to a precision of 1 part per million at a resolution of about 3 square kilometres - nearly 30 times that of the Japanese Greenhouse gases Observing Satellite (GOSAT, also known as IBUKI), which launched in January.
Replacing the OCO will cost about the same as the original $\$ 280$-million mission, says Crisp; if funding continues to be granted, the observatory could be launched as early as 2013 .

That would require a much bigger budget for fiscal year 2011, but because NASA is one of several science agencies not included in a targeted doubling of basic-science funding (see "Will the budget bubble burst?'), it may well face a flat budget next year. "Or worse," says Moore.

NASA already has a list of 15 other Earthscience missions that were identified in a decadal survey' to prioritize missions over the next ten years. In the spending bill, Congress said it was "concerned" about the limited progress of those missions, and gave $\$ 15$ million to accelerate two that are intended to monitor global climate change. It has also instructed NASA to look at using commercial providers, following the lead of a panel that reviewed the agency's human spaceflight programme and earlier this year called for greater reliance on commercial rocket companies. missions being profitable enough for commercial companies to be interested in running them. In lieu of a surprise windfall in February's 2011 budget proposals, he says, NASA might need to delay the missions further: "We may have to rename the decadal programme the centennial."

Eric Hand
But Moore doesn't see the Earth-science

\section{Will the budget bubble burst?}

US science agencies saw modest budget rises for fiscal year 2010 after Congress approved a spending bill on 13 December. However, researchers are bracing themselves for tighter budgets in 2011 as the government clamps down on its deficit spending.

The National Institutes of Health received a $2.3 \%$ rise in funds for 2010 , although some observers say that is because the agency is still digesting a \$10.4-billion one-off infusion from the 2009 economic stimulus package.

NASA received a $5.3 \%$ rise, but funds for its \$4.5-billion science directorate were shaved down by $\$ 34$ million compared with last year. Despite small budgetary windfalls for specific climate-monitoring satellites (see main story), Earth scientists at NASA are worried about the long-term demands on their budget.

Basic-science agencies - the National Science Foundation, the National Institute of Standards and Technology and the energy department's Office of Science - are still on course to double their budgets within a decade, as dictated by the 2007 America COMPETES Act.

However, as the economy recovers and the government shifts its focus from stimulus spending to deficit cutting, some agencies are planning for flat or falling budgets in fiscal year 2011. "It's going to be a tough year," says Patrick Clemins, director of the research and development budget and policy programme at the American Association for the Advancement of Science in Washington DC.

E.H.

$\begin{array}{ll}\text { BUDGET GROWTH FOR } 2010 \\ \text { Agency } & \begin{array}{l}\text { Budget (per cent } \\ \text { increase on 2009) }\end{array} \\ \begin{array}{ll}\text { National Institutes } \\ \text { of Health }\end{array} & \begin{array}{l}\$ 31 \text { billion } \\ (2.3 \%)\end{array} \\ \text { NASA } & \begin{array}{l}\$ 18.7 \text { billion } \\ (5.3 \%)\end{array} \\ & \$ 4.9 \text { billion } \\ \text { Department of Energy, } & (2.7 \%) \\ \text { Office of Science } & \$ 6.9 \text { billion } \\ \text { National Science } & (6.7 \%) \\ \text { Foundation } & \$ 857 \text { million } \\ \text { National Institute of } & (4.6 \%)\end{array}$

